\title{
Lip and allar base dimensions among adolescence in healthy and post unilateral cleft lips correction in deutro-malaid population
}

\author{
Coen Pramono D \\ Department of Oral and Maxillofacial Surgery \\ Faculty of Dentistry Airlangga University \\ Surabaya - Indonesia
}

\begin{abstract}
The purpose of this study is to observe the differences between some anthropometric values of the lip and allar base area in normal and those who had undergone incomplete unilateral cleft lip surgical correction using Millard's I technique. The investigation was done on male und female adolescence of 12-15 years of age. Thirteen anthropometric dimension variables were observed, as $X 1=$ width of the allar base, $X 2=$ the distance between two corners of the mouth, $X 3=$ the distance between the center of the lip and the right mouth corner, $X 4=$ the distance between the center of the lip and the left mouth corner, X5 = the distance between the center of the allar base and the center of the of upper lip, X6 = the distance between upper part of two philtrum pillars, X7 = the distance between two philtrum pillars base, X8 = the height of right philtrum pillar, X9 = the height of left philtrum pillar, X10 = the distance between the right allar base to the right mouth corner, X11 = the distance between the left allar base to the left mouth corner, $X 12=$ the width of the right nostril, and X13 = the width of the left nostril. The t-test analysis showed the average of the anthropometric lip and allar base dimensions among male adolescence groups in variables of X1, X2, X4, X5, X6, X7, X10, X11, X12, and X13 shown with significant differences from those of some variables which had undergone incomplete unilateral cleft lip surgical correction $(p<0.05)$, and no significant differences shown in the variables of $X 3, X 6, X 8$, and $X 9(p>0.05)$. The result of the test among the female group presented a significant difference in variables of X4, X5, X6,X9,X11, X12 and X13 $(p<0.05)$, differed what given in variables of $X 1, X 2, X 3, X 7$ and $X 8$ showed with no significant difference ( $p>0.05)$. It concluded that there are differences in dimensions of the lips and allar bases among normal and post-surgical groups both in adolescence males and females.
\end{abstract}

Key words: Lip and allar base anthropometric dimensions, incomplete unilateral cleft lip post correction anthropometric dimensions, bird face Millard's I surgical technique

Correspondence: Coen Pramono D, c/o: Bagian Ilmu Bedah Mulut, Fakultas Kedokteran Gigi Universitas Airlangga. Jln. Mayjend. Prof. Dr. Moestopo No. 47 Surabaya 60132, Indonesia.

\section{INTRODUCTION}

Cleft lip is congenital abnormal space or gap in the upper lip, alveolus, or palate, the more appropriate terms are cleft lip, cleft palate or cleft lip and palate. This abnormality of growth occurs with unknown etiology. Some presumable factors are genetic, diseases, malnutrition, environment, and lack of certain substances in the intrauterine during the growing process.

To understand the causes of oral clefts, a review of nose, lip, and palate embryology is necessary. The entire process takes place between the fifth and tenth weeks of fetal life. ${ }^{1}$ Cleft lip result from a failure of merging of the middle portion of the upper lip which taken place between the fourth and eight weeks fetal life. ${ }^{2}$

The occurrence of oral clefts in United States has been estimated as 1 in 700 births $^{3}$ and in Indonesia no accurate data of cleft incidence is found. Cleft of the lip may range from a minute notch on the edge of the vermilion border to a wide cleft that extends in to nasal cavity and thus divides the nasal floor.
Cleft lip is the most common serious congenital anomaly to affect the oral region as this anomaly appearance may be grotesque because the deformity can be clearly seen therefore it might constitute a serious affliction to those who have it. Clinical appearance of individuals who have this defect sometimes can not be covered as they usually have a specific face and lip pattern which can only be seen in cleft lip patients.

There are many cleft surgical techniques developed to reconstruct the cleft lip with their advantage and disadvantages. Some famous cleft lip surgical techniques were presented by Rose, Mirault, Hagedron-LeMeurier, Tennyson, Tennyson-Cronin, Wynn, Millard, LeMesuire, and Skoog. ${ }^{4}$ All those surgical methods are focusing on skin and muscle closure, and used the opposite side as a guide in taking the measurement. Often seen un-proportional surgical result as the surgery is done can not exactly base on the opposite side of its healthy lip.

Two surgical report given by O'neal et al..$^{5}$ and Puccket et al., ${ }^{6}$ reported a surgical technique of lip reconstruction focusing on a necessary step to do a muscle reconstruction to achieve a good anatomical lip form. 
Amaratunga ${ }^{7}$ reported his work in observing the surgical result of cases with complete unilateral cleft lips had undergone surgery using Millard I and LeMesuire surgical techniques, done by comparing some lips components using symmetrical index. His study showed that the Millard I technique has an advantage in achieving of a good nostril and cupid's bow reformed, and the LeMesuire presented a good result for vermellion and philtrum correction.

In many publications of surgical techniques for cleft lips surgery are mentioned to the healthy site as the surgical guidance, the result of the surgery mostly is not based on the dimensions as usually used in orthodontic field. The surgical technique used is usually chosen by the surgeon and applied based on the surgeon experience and the surgical result expectation is the symmetrical result of the lip form in both sites.

Study of anthropometric of soft and hard facial tissues are given by many authors. Winoto ${ }^{8}$ in her study of Indonesian facial profile in Surabaya was done by analyzing the cephalometric radiography $\mathrm{x}$-ray and reported that in the population she had observed has the facial profile characteristic of a Deutro Malaid population.

Study of facial profile by Camper in $1768,{ }^{8}$ he reported his observation on the facial angle, which is created from perpendicular of two lines, line from points of Glabella (G) to Maxilla (A) points and a line from Porion (Po) to anterior Spina Nasalis (NS). This facial angle is important in determining the exact position of maxilla to cranial base.

Hamilah $^{9}$ reported her study of facial soft tissue development related to the facial skeletal bone growth in adolescence.

Schwarz in $1966^{9}$ reported his study of the prerequisite of harmonious facial soft tissue. He suggested a harmonious profile region named by Kiefer Profil Felt (KPF). This region is located behind the vertical line which taken in perpendicular from the soft tissue nasal tip to the horizontal line from Nasion $(\mathrm{N})$ to Orbita $(\mathrm{O})$ points defined as the KFP region. A harmonious face is categorized when lips and chin are located inside this vertical line.

Lips print pattern in Yogyakarta population was studied by Munakhir ${ }^{10}$ and he found that lips have its specific character according to its genes and the result of his study presented that lips have a print pattern which can be used for identification both in forensic and non forensic needs.

In general, human body has its own specific body pattern that might be grouped or differentiated from races and ethnic to other ethnic groups. Therefore lips and allar bases might have also a specific dimension in such ethnic groups

Indonesia has some varieties of ethnic groups believed to be the result of the migration of people from North Mongolia, China, Arab and Europe. ${ }^{8}$ Glinka ${ }^{11}$ reported his investigation on Indonesian population presented that Indonesian population gave a characteristic of at least
2 characters from 3 racial characters. Some other racial characters also found existed in other races and Fischer in year 1964 categorized the Javanese population in a group of Deutro-Malaid. ${ }^{8}$

Javanese population was recorded by citizen census in 1980 as the largest group population in Indonesia, ${ }^{12}$ therefore an anthropological observation on normal lip dimensions in Deutro-Malaid ethnic group was done for a control group and might be necessary to be used as a reference point in any anthropological setting.

Observation of the surgical result in incomplete unilateral cleft lip patients from Deutro-Malaid group used a Millard I surgical technique was done and comparing to those groups of the normal lips and allar bases region group from the same population.

\section{MATERIALS AND METHODS}

The study was carried out on 70 adolescence DeutroMalaid population varying from 12-15 years old males and females, consisted of 40 with healthy lips (HL) and 30 selected patients with incomplete unilateral cleft lip (IUCL) who had undergone surgical treatment using Millard I technique in the Department of Oral and Maxillofacial Surgery, Faculty of Dentistry, Gadjah Mada University during the year 1994-1995.

The HL group presented by 40 healthy lips students taken randomly from 440 students of The State Junior High School in Kotamadia Yogyakarta. All of 440 students taken for sample groups have a familial back ground of Javanese ancestor in 3 steps above.

Some anthropometric lip and allar base reference landmarks according to Martin and Knussmann ${ }^{13}$ were used and measured included: the width of the allar base $(\mathrm{Ac}-\mathrm{Ac})=\mathrm{X} 1$, the distance between two mouth corners $(\mathrm{Ch}-\mathrm{Ch})=\mathrm{X} 2$, the distance between the middle of upper lip to right mouth corner $(\mathrm{Ls}-\mathrm{ChR})=\mathrm{X} 3$, the distance between the middle of upper lip to le $\mathrm{ft}$ mouth corner $(\mathrm{Ls}-\mathrm{ChL})=\mathrm{X} 4$, the distance between the middle of allar base to the middle of the upper lip $(\mathrm{Sn}-\mathrm{Ls})=\mathrm{X} 5$, the distance between two point of the upper philtrum pillar $(\mathrm{X}-\mathrm{Y})=\mathrm{X} 6$ the distance between two point in the philtrum pillar base $(\mathrm{X} 1-\mathrm{Y} 1)=7$, the height of right philtrum $(\mathrm{X}-\mathrm{X} 1)=\mathrm{X} 8$, the height of left philtrum $(\mathrm{Y}-\mathrm{Y} 1)=\mathrm{X}$, the distance between right allar base to right mouth corner $(\mathrm{AcR}-\mathrm{ChR})=\mathrm{X} 10$, the distance between left allar base to left mouth corner $(\mathrm{AcR}-\mathrm{ChR})=\mathrm{X} 11$, the width of right nostril $(\mathrm{Np}-\mathrm{Np}$ 'R $)=\mathrm{X} 12$, the width of left nostril $(\mathrm{Np}-\mathrm{Np} \cdot \mathrm{R})=\mathrm{X} 13$ and measured with sliding ruler caliper in millimeter ( $\mathrm{mm})$.

Two way analysis of variance was used and followed by $\mathrm{T}$-Test to analysis the statistical differences between the data. 


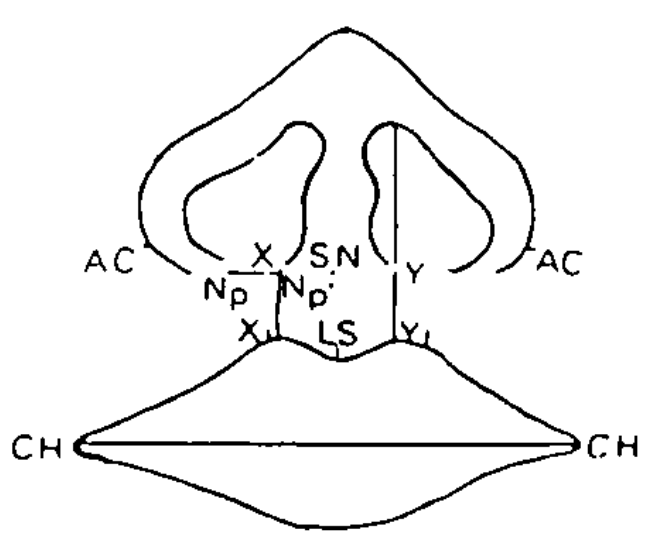

Figure 1. Some antrhopometric landmarks and some points were created for his purpose of investigation. ${ }^{13}$
Anthropometric landmarks notes:

$\mathrm{Np}-\mathrm{Np}^{\prime}=$ Inner nasal diameter

$\mathrm{X}-\mathrm{X} 1=$ Philtrum pillar height right side

$\mathrm{Y}-\mathrm{Y} 1=$ Philtrum pillar height left side

$\mathrm{SN} \quad=$ Nasal base point

LS = Upper Lip center point

\section{RESULTS}

The result of measurement on lips and allar bases landmarks measured in HL group and UCL group can be seen as follows:

\section{HL and IUCL in male groups}

Tabel 1. The result of measurements in average $(\mathrm{cm})$ of lips and allar bases in HL and IUCL adolescence males groups

\begin{tabular}{ccccccccccc}
\hline \multicolumn{3}{c}{ HL-A1B1 } & \multicolumn{3}{c}{ IUCL-A2B1 } \\
\hline Variable & Average & SD & N & Min & Max & Average & SD & N & Min & Max \\
\hline X1 & 3,200 & 0,283 & 20 & 2,500 & 3,600 & 3,447 & 0,220 & 15 & 3,00 & 3,700 \\
X2 & 4,330 & 0,334 & 20 & 3,600 & 4,800 & 4,607 & 0,335 & 15 & 4,100 & 5,100 \\
X3 & 2,780 & 0,399 & 20 & 2,200 & 3,700 & 2,860 & 0,203 & 15 & 2,700 & 3,200 \\
X4 & 2,660 & 0,307 & 20 & 2,100 & 3,200 & 2,907 & 0,252 & 15 & 2,700 & 3,200 \\
X5 & 1,285 & 0,195 & 20 & 1,100 & 1,700 & 1,127 & 0,183 & 15 & 0,600 & 1,300 \\
& & & & & & & & & & \\
X6 & 0,732 & 0,144 & 20 & 0,550 & 0,900 & 0,800 & 0,165 & 15 & 0,500 & 1,100 \\
X7 & 1,255 & 0,172 & 20 & 0,950 & 1,500 & 1,427 & 0,294 & 15 & 0,900 & 2,100 \\
X8 & 1,250 & 0,158 & 20 & 1,050 & 1,650 & 1,293 & 0,167 & 15 & 1,100 & 1,600 \\
X9 & 1,250 & 0,158 & 20 & 1,050 & 1,650 & 1,327 & 0,308 & 15 & 0,900 & 1,900 \\
X10 & 2,092 & 0,187 & 20 & 1,800 & 2,500 & 2,367 & 0,226 & 15 & 2,00 & 2,700 \\
& & & & & & & & & & \\
X11 & 2,037 & 0,280 & 20 & 1,800 & 2,500 & 2,400 & 0,151 & 15 & 2,200 & 2,700 \\
X12 & 0,780 & 0,189 & 20 & 0,550 & 1,050 & 1,053 & 0,223 & 15 & 0,700 & 1,500 \\
X13 & 0,745 & 0,146 & 20 & 0,550 & 0,950 & 1,120 & 0,345 & 15 & 0,700 & 1,400 \\
\hline
\end{tabular}

Adolescence female group

Table 2. The result of measurements in average $(\mathrm{cm})$ of lips and allar bases in HL and IUCL adolescence females groups

\begin{tabular}{ccccccccccc}
\hline \multicolumn{3}{c}{ HL-A1B2 } \\
\hline Variable & Average & SD & N & Min & Max & Average & SD & N & Min & Max \\
\hline X1 & 3,220 & 0,283 & 20 & 2,500 & 3,600 & 3,347 & 0,220 & 15 & 3,000 & 3,700 \\
X2 & 4,325 & 0,334 & 20 & 3,600 & 4,800 & 4,173 & 0,335 & 15 & 2,900 & 4,600 \\
X3 & 2,760 & 0,399 & 20 & 2,200 & 3,700 & 2,787 & 0,203 & 15 & 2,600 & 2,900 \\
X4 & 2,595 & 0,307 & 20 & 2,100 & 3,200 & 3,033 & 0,252 & 15 & 2,700 & 3,200 \\
X5 & 1,135 & 0,195 & 20 & 1,100 & 1,700 & 0,927 & 0,193 & 15 & 0,600 & 1,200 \\
& & & & & & & & & & \\
X6 & 0,865 & 0,144 & 20 & 0,550 & 0,900 & 0,640 & 0,165 & 15 & 0,500 & 0,800 \\
X7 & 1,232 & 0,172 & 20 & 0,950 & 1,500 & 1,280 & 0,294 & 15 & 1,000 & 1,400 \\
X8 & 1,160 & 0,158 & 20 & 1,050 & 1,650 & 1,200 & 0,167 & 15 & 0,800 & 1,600 \\
X9 & 1,160 & 0,158 & 20 & 1,050 & 1,650 & 1,347 & 0,308 & 15 & 0,800 & 1,600 \\
X10 & 2,092 & 0,187 & 20 & 1,800 & 2,500 & 2,213 & 0,224 & 15 & 2,100 & 2,400 \\
& & & & & & & & & \\
X11 & 2,070 & 0,280 & 20 & 1,800 & 2,500 & 2,240 & 0,151 & 15 & 2,100 & 2,400 \\
X12 & 0,877 & 0,189 & 20 & 0,550 & 1,050 & 1,107 & 0,223 & 15 & 0,800 & 1,500 \\
X13 & 0,842 & 0,146 & 20 & 0,550 & 0,950 & 1,087 & 0,345 & 15 & 0,700 & 1,300 \\
\hline
\end{tabular}


Table 3. Summary measurement result of 2 way analysis of variance on lips and allar bases dimensions between adolescence HL and IUCL males and females adolescence group

\begin{tabular}{|c|c|c|c|c|c|c|c|}
\hline Sources & Variable & $\mathrm{SSq}$ & Df & $\mathrm{MSq}$ & $\mathrm{F}$ & $\mathrm{R}^{2}$ & $\mathrm{P}$ \\
\hline Between A & $\mathrm{X} 1$ & 0,597 & 1 & 0,597 & 8,448 & 0,112 & $0,005^{*}$ \\
\hline \multirow[t]{12}{*}{ (HL-IUCL) } & $\mathrm{X} 2$ & 0,067 & 1 & 0,067 & 0,589 & 0,007 & 0,548 \\
\hline & X3 & 0,049 & 1 & 0,049 & 0,707 & 0,010 & 0,592 \\
\hline & $\mathrm{X} 4$ & 2,011 & 1 & 2,011 & 27,309 & 0,286 & $0,000^{*}$ \\
\hline & X5 & 0,575 & 1 & 0,575 & 14,494 & 0,155 & $0,001 *$ \\
\hline & X6 & 0,106 & 1 & 0,106 & 6,571 & 0,069 & $0,012 *$ \\
\hline & $\mathrm{X} 7$ & 0,206 & 1 & 0,206 & 4,294 & 0,058 & $0,040^{*}$ \\
\hline & $\mathrm{X} 8$ & 0,030 & 1 & 0,030 & 1,033 & 0,014 & 0,314 \\
\hline & X9 & 0,297 & 1 & 0,297 & 6,539 & 0,088 & $0,012 *$ \\
\hline & $\mathrm{X} 10$ & 0,669 & 1 & 0,669 & 16,985 & 0,194 & 0,000 \\
\hline & $\mathrm{X} 11$ & 1,215 & 1 & 1,125 & 29,035 & 0,291 & $0,000^{*}$ \\
\hline & $\mathrm{X} 12$ & 1,082 & 1 & 1,082 & 22,995 & 0,251 & $0,000^{*}$ \\
\hline & $\mathrm{X} 13$ & 1,643 & 1 & 1,643 & 30,061 & 0,307 & $0,000^{*}$ \\
\hline Between B & $\mathrm{X} 1$ & 0,017 & 1 & 0,017 & 0,244 & 0,003 & 0,629 \\
\hline \multirow[t]{12}{*}{ (Gender) } & $\mathrm{X} 2$ & 0,622 & 1 & 0,622 & 5,463 & 0,069 & $0,021 *$ \\
\hline & $\mathrm{X} 3$ & 0,032 & 1 & 0,032 & 0,466 & 0,007 & 0,504 \\
\hline & $\mathrm{X} 4$ & 0,005 & 1 & 0,005 & 0,070 & 0,001 & 0,768 \\
\hline & X5 & 0,516 & 1 & 0,516 & 13,015 & 0,139 & $0,001 *$ \\
\hline & X6 & 0,001 & 1 & 0,001 & 0,005 & 0,001 & 0,810 \\
\hline & $\mathrm{X} 7$ & 0,100 & 1 & 0,100 & 2,093 & 0,028 & 0,149 \\
\hline & $\mathrm{X} 8$ & 0,146 & 1 & 0,146 & 5,073 & 0,070 & $0,026^{*}$ \\
\hline & X9 & 0,032 & 1 & 0,032 & 0,707 & 0,010 & 0,592 \\
\hline & $\mathrm{X} 10$ & 0,076 & 1 & 0,076 & 1,920 & 0,022 & 0,147 \\
\hline & X11 & 0,044 & 1 & 0,044 & 1,045 & 0,010 & 0,311 \\
\hline & $\mathrm{X} 12$ & 0,108 & 1 & 0,108 & 2,296 & 0,025 & 0,131 \\
\hline & X13 & 0,030 & 1 & 0,030 & 0,550 & 0,006 & 0,532 \\
\hline \multirow[t]{13}{*}{ Between AB } & $\mathrm{X} 1$ & 0,062 & 1 & 0,062 & 0,873 & 0,012 & 0,644 \\
\hline & $\mathrm{X} 2$ & 0,786 & 1 & 0,786 & 6,903 & 0,087 & $0,010^{*}$ \\
\hline & X3 & 0,012 & 1 & 0,012 & 9,177 & 0,003 & 0,679 \\
\hline & $\mathrm{X} 4$ & 0,157 & 1 & 0,157 & 2,138 & 0,022 & 0,145 \\
\hline & X5 & 0,011 & 1 & 0,011 & 0,265 & 0,003 & 0,165 \\
\hline & X6 & 0,367 & 1 & 0,367 & 22,662 & 0,238 & $0,000^{*}$ \\
\hline & $\mathrm{X} 7$ & 0,066 & 1 & 0,066 & 1,379 & 0,019 & 0,243 \\
\hline & $\mathrm{X} 8$ & 0,000 & 1 & 0,000 & 0,002 & 0,000 & 0,967 \\
\hline & X9 & 0,052 & 1 & 0,052 & 1,141 & 0,015 & 0,289 \\
\hline & $\mathrm{X} 10$ & 0,101 & 1 & 0,101 & 2,559 & 0,029 & 0,111 \\
\hline & X11 & 0,159 & 1 & 0,159 & 3,794 & 0,038 & 0,053 \\
\hline & $\mathrm{X} 12$ & 0,000 & 1 & 0,000 & 0,178 & 0,002 & 0,678 \\
\hline & X13 & 0,073 & 1 & 0,073 & 1,342 & 0,014 & 0,249 \\
\hline \multirow[t]{5}{*}{ Inner } & $\mathrm{X} 1$ & 4,667 & 66 & 0,071 & - & - & - \\
\hline & $\mathrm{X} 2$ & 7,518 & 66 & 0,114 & - & - & - \\
\hline & X3 & 4,553 & 66 & 0,069 & - & - & - \\
\hline & $\mathrm{X} 4$ & 4,860 & 66 & 0,074 & - & - & - \\
\hline & $\mathrm{X} 5$ & 2,617 & 66 & 0,040 & - & - & - \\
\hline
\end{tabular}


Table 3 (lanjutan)

\begin{tabular}{|c|c|c|c|c|c|c|c|}
\hline Sources & Variable & $\mathrm{SSq}$ & Df & $\mathrm{MSq}$ & $\mathrm{F}$ & $\mathrm{R}^{2}$ & $\mathrm{P}$ \\
\hline \multirow[t]{8}{*}{ Inner } & X6 & 1,068 & 66 & 0,016 & - & - & - \\
\hline & $\mathrm{X} 7$ & 3,164 & 66 & 0,048 & - & - & - \\
\hline & $\mathrm{X} 8$ & 1,902 & 66 & 0,029 & - & - & - \\
\hline & X9 & 3,000 & 66 & 0,045 & - & - & - \\
\hline & X10 & 2,598 & 66 & 0,039 & - & - & - \\
\hline & X11 & 2,762 & 66 & 0,042 & - & - & - \\
\hline & $\mathrm{X} 12$ & 3,106 & 66 & 0,047 & - & - & - \\
\hline & X13 & 3,607 & 66 & 0,055 & - & - & - \\
\hline \multirow[t]{13}{*}{ Total } & $\mathrm{X} 1$ & 5,343 & 69 & - & - & - & - \\
\hline & $\mathrm{X} 2$ & 8,994 & 69 & - & - & - & - \\
\hline & $\mathrm{X} 3$ & 4,646 & 69 & - & - & - & - \\
\hline & $\mathrm{X} 4$ & 7,034 & 69 & - & - & - & - \\
\hline & X5 & 3,718 & 69 & - & - & - & - \\
\hline & X6 & 1,542 & 69 & - & - & - & - \\
\hline & $\mathrm{X} 7$ & 3,536 & 69 & - & - & - & - \\
\hline & $\mathrm{X} 8$ & 2,078 & 69 & - & - & - & - \\
\hline & X9 & 3,381 & 69 & - & - & - & - \\
\hline & X10 & 3,443 & 69 & - & - & - & - \\
\hline & X11 & 4,180 & 69 & - & - & - & - \\
\hline & $\mathrm{X} 12$ & 4,305 & 69 & - & - & - & - \\
\hline & X13 & 5,354 & 69 & - & - & - & - \\
\hline
\end{tabular}

The average difference among variables measured to HL and IUCL males and females adolescence groups. The result of the $\mathrm{T}$ Test statistical analysis can be shown in table 4 as follow.

Tabel 4. $\mathrm{T}$ Test measurement result average difference of lip and allar base size of HL and IUCL male and female group to inter $\mathrm{AB}$ source

\begin{tabular}{cllll}
\hline & \multicolumn{4}{c}{ Variation Sources } \\
\cline { 2 - 5 } Variables & \multicolumn{2}{c}{$\begin{array}{c}\text { A1B1-A2B1 } \\
\text { (male) }\end{array}$} & \multicolumn{2}{c}{$\begin{array}{c}\text { A1B2-A2B2 } \\
\text { (famele) }\end{array}$} \\
\cline { 2 - 5 } & t-test & \multicolumn{1}{c}{$\mathrm{p}$} & t-test & $\mathrm{P}$ \\
\hline X1 & 2,176 & $0,008^{*}$ & 1,395 & 0,164 \\
X2 & 2,400 & $0,018^{*}$ & 1,316 & 0,190 \\
X3 & 0,892 & 0,621 & 0,297 & 0,765 \\
X4 & 2,661 & $0,010^{*}$ & 4,729 & $0,000^{*}$ \\
X5 & 2,328 & $0,022^{*}$ & 3,506 & $0,004^{*}$ \\
& & & & \\
X6 & 1,554 & 0,121 & 5,179 & $0,000^{*}$ \\
X7 & 2,295 & $0,023^{*}$ & 0,635 & 0,535 \\
X8 & 0,747 & 0,536 & 0,690 & 0,500 \\
X9 & 1,053 & 0,297 & 2,563 & $0,012^{*}$ \\
X10 & 4,045 & $0,000^{*}$ & 1,783 & 0,076 \\
& & & & \\
X11 & 5,188 & $0,000^{*}$ & 2,433 & $0,017^{*}$ \\
X12 & 3,689 & $0,001^{*}$ & 3,093 & $0,003^{*}$ \\
X13 & 4,696 & $0,000^{*}$ & 3,058 & $0,004^{*}$ \\
\hline
\end{tabular}

Notes:

A1B1 = Healthy lip adolescence male group

$\mathrm{A} 2 \mathrm{~B} 1=$ Post incomplete cleft lip surgery to adolescence male group

A1B2 = Healthy lip adolescence female group

A2B2 = Post incomplete cleft lip surgery to adolescence female group

HL1 = Healthy lips group male

IUCL1 = Post correction of unilateral cleft lip male

HL2 = Healthy lips group female

IUCL2 = Post correction of unilateral cleft lip female

$\mathrm{X} 1=$ Allar base width $(\mathrm{AC}-\mathrm{AC})$

$\mathrm{X} 2=$ Mouth width $(\mathrm{CH}-\mathrm{CH})$

$\mathrm{X} 3=$ distance between the middle of lip to right mouth corner (Ls-ChR)

$\mathrm{X} 4=$ distance between the middle of lip to left mouth corner (Ls-ChL)

X5 = distance between allar base and the middle of the lip (Sn-Ls)

X6 = distance between two highest points of philtrum pillars $(\mathrm{X}-\mathrm{Y})$

$\mathrm{X} 7=$ distance between two lowest points of philtrum pillars (X1-Y1)

$\mathrm{X} 8=$ right philtrum height $(\mathrm{X}-\mathrm{X} 1)$

$\mathrm{X} 9=$ left philtrum height $(\mathrm{Y}-\mathrm{Y} 1)$

$\mathrm{X} 10=$ distance between right lateral allar base to right mouth corner (AcR-ChR)

$\mathrm{X} 11=$ distance between left lateral allar base to left mouth corner (AcL-ChL)

$\mathrm{X} 12=$ Right Nostril width (Np-Np'R)

$\mathrm{X} 13=$ Left Nostril width (Np-Np'L) 


\section{DISCUSSION}

This research was done to observe the lips and allar bases dimensions on 70 adolescence of 12-15 years of age, males and females with healthy lips group (HL) and post surgical correction of incomplete unilateral cleft lips group (IUCL) used a Millard I surgical technique.

The differences of lips and allars bases situation between 2 groups of HL and IUCL can be explained as follows.

\section{In males group}

The result of the analysis in male group presented that the surgical treatment can not reestablish the anthropometry dimensions, shown in variables of $X 1$ (Ac-Ac), X2 (Ch-Ch), X4 (LSChL), X5 (Sn-Ls), X7 (X1-Y1), X10 (AcR-ChR), X11 (AcL-ChL), X12 (Np-Np'R) and $\mathrm{X} 13$ (Np-Np'L) not as given in control group of (HL). This situation might be due to those variables of X1 (Ac-Ac), X5 (Sn-Ls), X10 (Ac-ChR), X11 (Ac-ChL), X12 (N-Np'R) and X13 (N-Np'L) are variables which included in the cleft side.

In variable $\mathrm{X} 2(\mathrm{Ch}-\mathrm{Ch})$ presumed to be a difficult landmark to measure as the landmark points are located in both this mouth corners known very unstable due to movements of muscles of the mouth. The orbicularis oris muscle consists anatomically and functionally of two parts, the superficial and the deep layers. The fibers of the superficial portion of the orbicularis oris muscle connect with the maxilla and septum above and with the mandible below. In the upper lip these fibers consist of two bands: the lateral band arises from alveolar process of the maxilla, opposite the lateral incisor tooth, the medial band connects the muscle with the septum. It is joined by the muscle of expression, which intermingle with it and participate in its function by their dilating or stabilizing effect or both. The superficial portion of the orbicularis oris muscle also brings the lips together and its fibers contract independently to provide fine shades of expression. The deep layers of muscles encircle the orifice of the mouth and function solely as mouth constrictor. ${ }^{14}$

In variables X3 (Ls-ChR) and X4 (Ls-ChL) shown with different result, this might be due the $\mathrm{X} 3(\mathrm{Ls}-\mathrm{ChR})$ not located in the cleft region but located in the normal side and the $\mathrm{X} 4(\mathrm{Ls}-\mathrm{ChL})$ is included in the cleft side.

In variables X3 (Ls-ChR), X6 (X-Y), X8 (X-X1, $\mathrm{X} 9$ (Y-Y1) shown with no significant differences between HL group and UCL group ( $\mathrm{p}>0.05)$.

In case of IUCL the Millard I used in the correction of group IUCL, resulted a good result in the correction of the philtrum, presented by variables, the distance between 2 points in the upper philtrum pillars abbreviated in $\mathrm{X} 6(\mathrm{X}-\mathrm{Y})$, and 2 philtrum pillars abbreviated in $\mathrm{X} 8(\mathrm{X}-\mathrm{X} 1)$ and $\mathrm{X} 9(\mathrm{Y}-\mathrm{Y} 1)$ statistically shown with no significance differences in these variables between HL and IUCL groups.

\section{In fameles group}

The result of analysis in females group presented that the surgical treatment can not reestablishing the anthropometry dimensions in some variables shown by no significance differences $(\mathrm{p}>0.05)$ in, $\mathrm{X} 1$ (Ac-Ac), X2 (Ch-Ch), X3 (Ls-ChR), X7 (X1-Y1), X8 (X-X1) and $\mathrm{X} 10(\mathrm{AcR}-\mathrm{ChR})$ and 7 variables shown with significantly difference $(\mathrm{p}<0.05)$ in $\mathrm{X} 4(\mathrm{Ls}-\mathrm{ChL}), \mathrm{X} 5$ (Sn-Ls), X6 (X-Y), X9 (Y-Y1), X11 (AcL-ChL), X12 (Np-Np'R) and $\mathrm{X} 13$ (Np-Np'L).

The same result as presented in the IUCL males group, surgical correction in IUCL can not perform the lips and allar bases dimensions perfectly when compared to the HL group.

In 6 variables observed found with no significant difference are not related closely to the incomplete unilateral cleft side which had undergone surgical correction, differed what shown in variables which closely related to the cleft side

\section{In male and famele groups}

From those 2 groups of males and females observed, shown that these groups have the same differences in variables of X4, X5, X11, X12 and X13 to control group of HL $(\mathrm{p}<0.05)$. This result represented that the lips form in males and females groups have the same post surgical result, that the lips form in IUCL and HL are different significantly $(\mathrm{p}<0.05)$.

In both groups of IUCL in males and females, a variable of X4 represented an important result for symmetrical situation of the upper lips. In IULC, the lateral defect of the orbicularis oris muscle related to the muscle discontinuity and lost part of the muscle tissue. Closure of one site muscle discontinuity would be brought the lip become shorter in its horizontal dimension therefore it is difficult to find a lip in symmetrical form or has a dimension as given by HL after a cleft lip surgical reconstruction.

The result of the observation in males on 13 variables taken from adolescence of 12-15 years old males and females from Deutro-Malaid groups shown that 9 variables were found different in X1, X2, X4, X5, X7, X10 X11, $\mathrm{X} 12$ and $\mathrm{X} 13$. In 4 other variables of $\mathrm{X} 3, \mathrm{X} 6, \mathrm{X} 8, \mathrm{X} 9$ found with no significantly differences.

Between males group, 7 variables were found difference in X4, X5, X6, X9, X11, X12 and X13. In other 6 variables of $X 1, X 2, X 3, X 7, X 8$ and $X 10$ found with no significant difference.

The result of this observation concluded that the lips and allar bases regions between IUCL group and HL group have different in dimensions.

In complete unilateral cleft lip, the fibers of the orbicularis oris muscle, proceeding horizontally from corner of the mouth towards the midline, turn upwards along the margins of the cleft. They terminate laterally beneath the base of the alla of the nose and medially beneath 
the base of columnella, in which most of them attach themselves to the periosteum of the maxilla, a few disappearing in the subcutis. ${ }^{14}$

In cleft lip patients the maxillo-premaxilla structures usually disturbed during the growing process, therefore an anomaly in this region usually clinically presented. Changes in the maxilla and premaxilla regions might lead to develop a nose in asymmetry. The cartilage bone raised and bended to the direction of uncleft side, and might cause the collumella shorten and slanting to the cleft side. The amount of soft tissue lost in patients with unilateral cleft lips might present with different clinical appearance from patient to another patient. The lost of the orbicularis oris muscle continuity related to the degree of anatomical lip defect severity and in this observation can be presented by 7 variables observed, in which this muscle should be proceed horizontally in nature.

The lips defect which given by birth caused by the orbicularis oris discontinuity usually also followed by skeletal defect. In patients who had suffered from cleft lip in any grades of severity and had undergone surgical correction therefore should not be compared to a healthy lip, as in the cleft lips, the total length of lips in born given could be found shorter then normal.

The symmetrical lip analysis as reported by Amaratunga ${ }^{7}$ might be the best method can be used to evaluate the surgical result in any degrees of cleft lips. The post surgical lip correction found in symmetry would be clinically more acceptable and found with beauty then corrected into an anthropology millimeter norm but found with unrealistic lip form.

The control groups of healthy lips in adolescence Deutro-Malaid population at Kotamadia Yogyakarta had taken as a preliminary group for having the lips and allar bases anthropometric dimensions data should be further observed by increasing the number of the sample groups to achieve more representative and accurate data. Those dimension values found in the control group might be important in contributing the anthropology literatures in the future.

\section{ACKNOWLEDGEMENT}

I would like to express my gratitude to the The Department of Higher Education, Students, Teachers, Head
Misters of the State Secondary High School at Kotamadia Jogjakarta for their great contribution made this research possible to be done.

\section{REFERENCES}

1. Langman J. Medical embryology. $3^{\text {rd }}$ ed. Baltimore: William and Wilkin; 1975. p. 1-6.

2. Stevenson RE, Hall JG, Goodman RM. Human related anomalies. New York: Oxford University Press; 1993. p. 39-79.

3. Jones C. The genetic of cleft lip and palate: Information for families, Chapel Hill, NC. Booklet Cleft Palate Foundation, 2000.

4. Krueger GO. Textbook of oral surgery. $4^{\text {th }}$ ed. St Louis: The CV Mosby Co; 1974. p. 192-293.

5. O'Neal RM, Greer DM, Nobel GL. Secondary correction of bilateral cleft lip deformities with Millard's midline muscular closure. Plastic and Reconstructive Surgery J 1974; 54(1):45-51.

6. Puccket CL, Reinisch JF, Warner RS. Late correction of orbicularis discontinuity in bilateral cleft. Cleft Palate J 1980 January; 17(1):34-9.

7. Amaratunga NA. A comparasion of Millard's and LeMesuirer's methods of of repair of the complate unilateral cleft Lip using a new symetry index. J Oral Maxillofac Surg 1988; 46:353-6.

8. Winoto NS. Studi profil fasial Indonesia di Surabaya dengan pendekatan sefalometrik. Desertasi. 1981.

9. Hamilah D. Pola pertumbuhan jaringan lunak kraniofasial serta kaitannya dengan pola pertumbuhan jaringan keras kraniofasial dan pertumbuhan umum. Kajian sefalometrik- rontgenografik dan fotometrik pada anak usia 6-18 tahun. Desertasi. Jakarta: Universitas Indonesia; 1991.

10. Munakhir MS. Pola sidik bibir penduduk propinsi Daerah Istimewa Yogyakarta. Kajian pada kelompok populasi Jawa dan Cina di Sekolah Menengah Atas Kotamadya Yogyakarta. Thesis. Yogyakarta: Universitas Gadjah Mada; 1995.

11. Glinka J. Gestelt und herkunft: Betrag zur antrophologischer Kleiderung Indonesiens. Studia Instituti Antropos. Angestin. Bein Bonn Verlag des Antropos Institute 1978; 35:155-6.

12. Rasyid A. Penduduk Indonesia: Hasil sensus penuduk 1980. Biro Pusat Statistic Jakarta; 1980. Seri no. 2.

13. Martin R, Knussman G. Handbuch der vergleichenden Biologi des Menschen. Band I. Stuttgart: Gustav Fischer Verlag; 1988. p. 192-293.

14. Fara M. The musculature of cleft lip and palate. In: Reconstructive plastic surgery. Principles and procedures in correction, reconstruction and transplantation. $2^{\text {nd }}$ ed. Philadelphia: WB Saunders Co; 1977. p. 1966-88. 